\title{
Auricular pseudocyst in a woman
}

\author{
Ron Tupker, ${ }^{1}$ Johan Toonstra ${ }^{2}$
}

${ }^{1}$ Department of Dermatology, St Antonius Hospital, Nieuwegein, The Netherlands ${ }^{2}$ Department of Dermatology, University Medical Center Utrecht, Utrecht, The Netherlands

\section{Correspondence to}

Dr Ron Tupker,

r.tupker@planet.nl
To cite: Tupker $\mathrm{R}$ Toonstra J. BMJ Case Rep Published online: [please include Day Month Year] doi:10.1136/bcr-2013010157

\section{DESCRIPTION}

A 33-year-old woman presented with a 4-week history of a painless swelling of her left ear. She denied a blunt trauma or a freezing episode. There was no local redness or suppuration, and no problems in joint. Her medical history was unremarkable, except for migraine.

On examination the cranial part of the helix of the left ear, spreading to the adjacent antehelix had a soft subdermal bulgy swollen appearance with a slightly bluish colour (figure 1).

When taking the biopsy a translucent jelly-like material evacuated. Microscopic examination revealed no epidermal and dermal changes. The deepest part of the biopsy showed a fibrocartilagious layer with proliferating fibroblasts at the dermal site of it.

On a subsequent visit 2 weeks later the ear had totally recovered. Then she admitted her habit of twisting her ears.

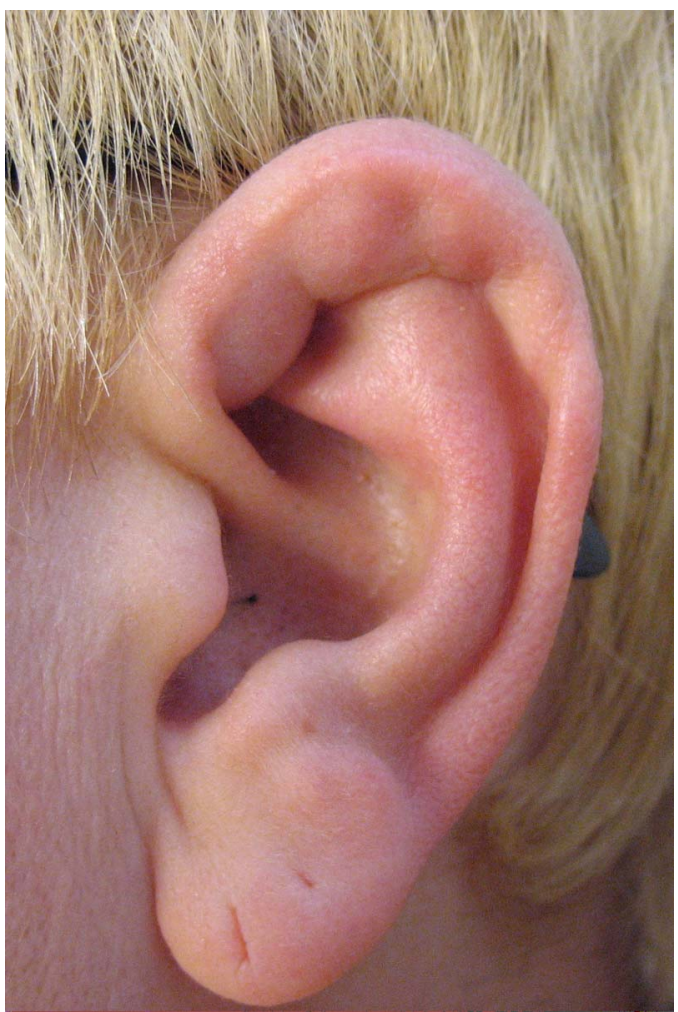

Figure 1 Soft subdermal bulgy swollen appearance of the cranial part of the helix of the left ear, spreading to the adjacent antihelix.
Auricular pseudocysts are seen almost exclusively in men who participate in wrestling or boxing. ${ }^{1}$ Shearing forces are responsible for the building of serous fluid in the subperichondrial space. In case blood vessels are ruptured an auricular haematoma will develop. It is mandatory to evacuate the fluid within 7 days by either aspiration or surgical incision to ensure sufficient drainage. ${ }^{2}{ }^{3}$ A compressing dressing is needed in most cases. In case of infection oral antibiotics may be necessary. If left untreated, the fluids can organise into a solid mass, with subsequent calcification, which is known as petrified ear.

More permanent damage may lead to neocartilage formation, known as cauliflower ear or wrestler's ear.

\section{Learning points}

- (Repetitive) Trauma to the ear avulses the perichondrium from the underlying cartilage, which may be followed by serous liquid or haematoma formation.

- Although this condition is classically seen in male wrestlers and boxers, we have demonstrated the same condition in a woman with the habit of twisting her ears.

- It is mandatory to evacuate the fluid by either aspiration or surgical incision to ensure sufficient drainage. A compressing dressing is needed in most cases in order to prevent the forming of fibroneocartilage, followed by calcification.

Contributors JT has been involved in the diagnostic process, and in writing of the manuscript.

Competing interests None.

Patient consent Obtained.

Provenance and peer review Not commissioned; externally peer reviewed.

\section{REFERENCES}

1 Burgdorf WHC, Plewig G, Landthaler M, et al. Braun-Falco's dermatology: Cauliflower ear. 3rd edn. Heidelberg: Springer Medizin Verlag, 2009:1111.

2 Ghanem T, Rasamny JK, Park SS. Rethinking auricular trauma. Laryngoscope 2005;115:1251-5.

3 Roy S, Smith LP. A novel technique for treating auricular hematomas in mixed martial artists (ultimate fighters). $A m$ J Otolaryngol 2010;31:21-4. 


\section{Images in...}

Copyright 2013 BMJ Publishing Group. All rights reserved. For permission to reuse any of this content visit http://group.bmj.com/group/rights-licensing/permissions.

BMJ Case Report Fellows may re-use this article for personal use and teaching without any further permission.

Become a Fellow of BMJ Case Reports today and you can:

- Submit as many cases as you like

- Enjoy fast sympathetic peer review and rapid publication of accepted articles

- Access all the published articles

- Re-use any of the published material for personal use and teaching without further permission

For information on Institutional Fellowships contact consortiasales@bmjgroup.com

Visit casereports.bmj.com for more articles like this and to become a Fellow 